\title{
El compadrazgo de esclavos en el siglo XVIII en la parroquia de Nuestra Señora del Socorro (Nuevo Reino de Granada)*
}

\section{Slaves Godparentage during the XVIII Century at the Parish of Nuestra Señora del Socorro (New Kingdom of Granada)}

\author{
Robinson Salazar Carreño \\ ORCID iD: http://orcid.org/0000-0001-9042-5843 \\ Universidad Manuela Beltrán, Colombia
}

\begin{abstract}
El artículo analiza los lazos de parentesco establecidos por los esclavos a través del sacramento del bautismo en la parroquia de Nuestra Señora del Socorro (virreinato de la Nueva Granada), en el período comprendido entre 1700 y 1779. Se busca llenar un vacío en la historiografía de Colombia en lo referente al tema. El objetivo es mostrar la diversidad de los vínculos de compadrazgo en la población cautiva estudiada, la cual privilegió a los padrinos y madrinas de condición libre. La hipótesis central consiste en que los esclavos fueron los protagonistas de su propia existencia, haciendo del compadrazgo el mecanismo para mejorar en la vida.
\end{abstract}

Palabras Clave: Nuestra Señora del Socorro; Esclavitud; Compadrazgo; Siglo XVIII.

This article analyses the relative bonds established by the slaves through the sacrament of baptism at the parish of Nuestra Señora del Socorro (Viceroyalty of New Granada), in the period comprehended between 1700 and 1779. We aim to fill the historiographical gap existing in Colombia related to this topic. Our purpose is to display the diversity of the godparentage relations within the captive population studied. Such condition privileged those godparents who were free. The main hypothesis consists that the slaves had the main role in their existence, due to the fact that they used the godparentage relations to improve their quality of life.

KeYwords: Nuestra Señora del Socorro; Slavery; Godparentage Relations; XVIII Century.

Copyright: (C) 2019 CSIC. Este es un artículo de acceso abierto distribuido bajo los términos de la licencia de uso y distribución Creative Commons Reconocimiento 4.0 Internacional (CC BY 4.0).

* Este artículo se basa en el último capítulo de mi tesis para optar por el título de doctor en Historia en El Colegio de México, obtenido en 2017. La investigación se realizó gracias al apoyo financiero y académico de dicha institución y del Consejo Nacional de Ciencia y Tecnología (Conacyt). 
En el presente artículo se propone mostrar los nexos de compadrazgo establecidos por los esclavos de la parroquia de Nuestra Señora del Socorro (virreinato de la Nueva Granada) durante las primeras ocho décadas del siglo XVIII. ${ }^{1}$ La investigación se basa en la información hallada en los libros de bautismos de la mencionada feligresía, custodiados en el Archivo Histórico Regional, ubicado en la Universidad Industrial de Santander (Bucaramanga), documentación también disponible en el Archivo General de la Nación de Colombia, en Bogotá, y en el sitio web Familysearch.org. Del corpus documental investigado se seleccionaron aquellos registros en los cuales los cautivos recibieron el sacramento del bautismo, así como los casos de hijos de esclavos varones y mujeres libres, 556 y 95 asientos respectivamente. ${ }^{2}$ A través de esta información se pretende reconstruir cómo los cautivos se constituyeron en protagonistas de su existencia, al tejer lazos familiares y sociales ventajosos para ellos que rebasaban los nexos familiares y los de las propiedades esclavistas de las que formaron parte, procurando mejorar sus condiciones y, por qué no, medrar en su vida. ${ }^{3}$ Dos preguntas estructuran el examen de la información recolectada: ¿quiénes fueron los padrinos y madrinas de los hijos de los esclavos? y ¿a qué se debió esta elección?

Cabe recordar que para el Catolicismo el bautismo es el ingreso ritual de una persona en la Iglesia católica, cuerpo de Cristo. ${ }^{4}$ El bautismo es el primero de los sacramentos cristianos, se nace espiritualmente, se introduce a cada recién nacido al rebaño de Dios, y por medio de este se perdona y lava el pecado original. ${ }^{5}$ Asimismo, quien no recibe este sacramento queda impedido para cumplir los demás (comunión, confirmación, penitencia, matrimonio o sacerdocio y unción de los enfermos). ${ }^{6}$ Sin embargo, en la práctica cotidiana, este sacramento llegaba a tener significados más amplios al ámbito religioso, al reforzar o suscitar relaciones de amistad y

1 Por medio de otros sacramentos también se establecían relaciones de compadrazgo, como el matrimonio y la confirmación, pero solo me concentro en el bautismo por encontrar información mucho más completa y continua que permite realizar un estudio sistemático. En el caso de las confirmaciones, no las he hallado para el período abordado, y en el de los matrimonios, no siempre se incluyó el registro de los padrinos.

2 Desde el Concilio de Trento (1545-1563), la orden del alto clero consistió en que en todas las parroquias se separaran los libros de sacramentos para libres y esclavos. Sin embargo, en la práctica, no siempre se hizo de este modo, como en el caso de El Socorro, encontrándose volúmenes en los que se registraron a todos los sectores de la población.

3 Schwartz, 1995, 331.

4 Brügger, 2002, 319; Scott, 2008, 138.

5 Cruz, 2006, 67.

6 Nacif, 2014, 23; Venâncio, Sousa y Pereira, 2006, 274. 
solidaridad entre personas de estatus iguales y diferentes, extendiendo los lazos de parentesco más allá de los estrictamente consanguíneos y matrimoniales. ${ }^{7}$ El bautismo creaba nexos estrechos y duraderos no solamente entre los ahijados, los padrinos, los compadres y los progenitores del bautizado, sino que unía a sus respectivas familias. ${ }^{8}$ En palabras de Guido Alfani, «el bautizo, de hecho, no realizaba solo el nacimiento espiritual del nuevo cristiano, sino también su nacimiento social». ${ }^{9}$

Los padrinos y madrinas debían velar por la educación religiosa de su ahijado. ${ }^{10}$ Desde el ángulo secular, los padrinos se constituían en el punto de apoyo para el bautizado y su familia en los momentos de vulnerabilidad socio-económica y de salud. ${ }^{11}$ Estos ejercían una co-paternidad —eran los «padres espirituales»—, estableciéndose un conjunto de auxilios y favores recíprocos: apoyaban en la crianza y enseñanza de alguna habilidad o destreza de sus ahijados, como por ejemplo, leer y escribir, la práctica de un oficio y la posibilidad de acceso a cierto cargo. Por ende, este vínculo tenía fines utilitarios para la vida social de las personas. ${ }^{12}$ En el caso de los esclavos, los amos eran los responsables de llevarlos a la pila bautismal, sufragar los gastos de la ceremonia y velar por su adoctrinamiento. ${ }^{13}$ Sin embargo, el cumplimiento de estas tareas era compartido con los padrinos. Además, con las actas bautismales los señores probaban la posesión de un esclavo y los libertos demostraban su propia libertad. ${ }^{14}$

No obstante, los registros parroquiales concernientes a los esclavos son los más deficientes y problemáticos. Como la mayoría de ellos carecía de un apellido, la referencia básica para identificarlos era el nombre del amo, pero en muchos de los casos no se dejó constancia de esta información. Además, los curas eran descuidados al apuntar otros datos fundamentales para los análisis demográficos, tales como el apellido, los nombres de los padres, la vecindad, el rango generacional y la edad. Según Ana Silvia Volpi, para los eclesiásticos que hacían los registros bautismales la anotación

7 Schwartz, 1992, 139; O’toole, 2012, 56; Barcia, 2003, 113 y 118; Faria, 1998, 304; Pereira, 2004, 1.

8 Brügger, 2004, 3

9 Alfani, 2008, 90.

10 Periáñez, 2008, 334; Covarrubias, 1995, 336, 338 y 795.

11 Cruz, 2006, 71; Maia, 2010, 48.

12 Nacif, 2014, 19.

13 En Perú, O’toole encontró que los dueños de esclavos rurales en raras ocasiones corrían con los gastos parroquiales del bautizo de sus siervos, descargando esta responsabilidad en los progenitores. Véase O’toole, 2012, 56.

14 Venâncio, Sousa y Pereira, 2006, 275; Delfino, 2012, 4. 
de la ocupación de los padrinos y de los progenitores solo era considerada relevante si se asociaba con cargos administrativos, sacerdotales y patentes militares. ${ }^{15}$ Una cuestión señalada por Sheila de Castro Faria es que no se sabe quién transmitía la información del cautivo en los registros parroquiales, si eran ellos mismos, sus dueños, los párrocos u otras personas. ${ }^{16}$ Varios de los bautizados carecían de los datos relativos a su condición, calidad y propietario, pero sus progenitoras eran quienes les daban su lugar en la sociedad y su pertenencia al amo. En líneas generales, un registro de bautismo de un esclavo estaba constituido de la manera siguiente:

En la parroqa del Socorro en 18 de agosto de 49 Yo el Dr Dn Luis de Guzman baptise sub conditione puse oleo y chrisma a Bacilio de un año h. de Josepha esclava, su madrina Luisa Roleto esclava. Doy fe $=$ Dr Dn Luis de Guzman. ${ }^{17}$

\section{La amplitud de los vínculos de parentesco}

La parroquia de Nuestra Señora del Socorro — fundada en 1683 - era uno de los curatos de hispánicos que se encontraban dentro de los términos de la jurisdicción de la villa de San Gil (sede del ayuntamiento), de la cual distaba cinco leguas. ${ }^{18}$ Se localizaba al nororiente del virreinato de la Nueva Granada, al norte de Santafé (hoy Bogotá), en una zona montañosa en la que se sembraba maíz, tabaco, algodón y caña de azúcar en haciendas y en pequeñas explotaciones rurales campesinas. ${ }^{19} \mathrm{El}$ Socorro era la feligresía más populosa de la comarca, en donde confluían importantes caminos y era lugar de un dinámico intercambio de mercancías, como los lienzos de algodón elaborados en casa por sus habitantes, demandados en otras provincias neogranadinas. ${ }^{20}$

En El Socorro, los 556 esclavos consagrados en la pila bautismal tuvieron 443 padrinos y 153 madrinas. Además, hubo 95 bautizados que descendían de progenitor esclavo con madre libre, quienes tuvieron 80 padrinos y 26 madrinas. No obstante, cabe aclarar que hubo 22 registros con

15 Scott, 2008, 145.

16 Faria, 1998, 308.

17 Archivo Histórico Regional-Universidad Industrial de Santander (AHR-UIS), Archivo de la Parroquia de Nuestra Señora del Socorro (APS), Libro de bautismos de 1738-1753, año 1749, item (i.) 236 .

18 Guerrero y Martínez, 1997, 79-82.

19 McFarlane, 1997, 90; Salazar, 2011, 44; Guzmán, 1987, 57-59.

20 Oviedo, 1930, 174; Cortés, 1993, 36-37; Aprile-Gniset, 1991, 485 y 489. 
ausencia de ambos padrinos, aunque esto se debió más a la ilegibilidad de los folios que a la celebración repentina del sacramento ante el riesgo de muerte del párvulo. Además, del total de esclavos bautizados, únicamente el $11 \%$ (61 casos) tuvieron padrino y madrina. Asimismo, se presentaron dos registros con ambos padrinos hombres, lo que se constituyó en una transgresión de las normas eclesiásticas establecidas en Trento, ${ }^{21}$ pero revela la existencia de ciertas prácticas que flexibilizaban los cánones católicos. En general, se observó una participación más activa de los padrinos que de las madrinas, situación que variaba según los usos locales, como lo ha demostrado Alfani para la Europa medieval y moderna. ${ }^{22}$ Esto parece indicar una mayor apreciación del papel desempeñado por los varones en el establecimiento de parentescos rituales. ${ }^{23}$

El bautismo era un vínculo que asociaba a personas y parentelas en un amplio margen de relaciones, en los que los límites sociales, económicos y de calidades eran flexibles, aun involucrando a algunos cautivos. Así, muchos libres apadrinaron a esclavos, mientras que algunos de estos fueron seleccionados en el papel de ser padres espirituales para los hijos de los primeros. En particular, quince padrinos esclavos y tres madrinas de la misma condición se constituyeron en parientes espirituales de algunos libres. Por ejemplo, en 1766, un esclavo del doctor don Pedro Navarro, llamado Juan Joseph, apadrinó a la hija natural de Margarita Camacho, a quien nombraron María Petronila. ${ }^{24}$ Casos como estos revelan una tendencia por las asociaciones entre progenitores cautivos con padrinos y madrinas no esclavizados, incluso algunos establecieron nexos con gente influyente, que no necesariamente eran sus dueños.

Llama la atención el hecho de que únicamente dos de los hijos de las esclavas tuvieron la bendición de sus amos como parientes espirituales, ${ }^{25}$ lo que confirma la incompatibilidad entre los papeles desempeñados por los padrinos y los amos. ${ }^{26}$ Nicolás Camacho y el doctor don Diego Salvador Cortés fueron los únicos propietarios que apadrinaron a algunos de sus

21 El Concilio de Trento reguló la cantidad de padrinos y madrinas, estableciendo que bastaba con uno de los dos (hombre o mujer), y se podía admitir dos, uno de cada sexo. Véase, Alfani, 2008, 102.

22 Alfani, 2008, 94.

23 Brügger, 2002, 320; Cruz, 2006, 91; Nacif, 2014, 84-87.

24 AHR-UIS, APS, Libro de bautismos de 1766-1781, año 1766, i. 7.

25 Como se puede observar en algunas investigaciones para Brasil, no fue una práctica común que los amos apadrinaran a los hijos de sus esclavas. Véase, por ejemplo, Brügger, 2002, 322; Schwartz, 1992, 138; Maia, 2010, 42; Cruz, 2006, 94.

26 Schwartz, 1992, 147; Schwartz, 1995, 331; Machado, 2006, 67-68; Delfino, 2012, 7; Cruz, 2006,95 . 
esclavos durante el período analizado. En 1752, Camacho fue padrino de Margarita, hija de Lucía. ${ }^{27}$ Esta práctica, que vinculaba íntimamente a los cautivos con sus dueños, revela el uso de la consagración bautismal como mecanismo para reforzar la autoridad sobre los esclavos y su círculo de parientes - sean cautivos o libres-, así como lazos afectivos entre las partes. ${ }^{28}$ A diferencia de otros estudios, ${ }^{29}$ en El Socorro no fueron usuales los casos de amas que fuesen madrinas de la prole de sus esclavos. Con todo, como lo propone Cacilda Machado, es posible que cuando los hijos esclavos no eran apadrinados por sus propietarios, se podía elegir a un pariente o amigo cercano de ellos con el fin de tener un aliado que pudiera interferir en caso de conflictos. ${ }^{30} \mathrm{Tal}$ vez, estas fueron las situaciones de ciertos libres de ambos sexos y de las personas de prestigio social y político que llegaron a ser padrinos de cautivos, como se verá en el siguiente acápite.

Los esclavos socorranos privilegiaron como compadres y comadres a la población libre por encima de sus congéneres, sin importar la legitimidad del bautizado. ${ }^{31}$ Más aún se debe tener en cuenta que los cautivos se debieron relacionar cotidianamente con personas no esclavizadas, que según el padrón de 1779 predominaban en términos demográficos en la comarca. ${ }^{32}$ Además, otro elemento que ayuda a explicar la tendencia a elegir parientes espirituales libres es la preponderancia de la pequeña propiedad esclavista en la comarca de la villa de San Gil, en la cual, tres cuartas partes de 343 amos tenían entre uno y cuatro cautivos. ${ }^{33}$ Es evidente que una cantidad menor de integrantes de las esclavonías tendía a inclinar a los esclavos a entablar compadrazgos por fuera de su entorno inmediato.

De 443 padrinos, 44 eran esclavos, dos, mulatos libres y los otros 397, hombres libres $(89,6 \%)$. Es interesante encontrar entre los padrinos a un mulato libre - caso inusual entre los padres espirituales del curato-, como Francisco de Olave, quien apadrinó a Juan Isidro, hijo de María, esclava soltera, cuyo amo era Pedro Joseph Plata. ${ }^{34}$ La poca presencia de libres

27 AHR-UIS, APS, Libro de bautismos de 1738-1753, año 1752, i. 397.

28 Cruz, 2006, 74; Machado, 2006, 69.

29 Silvia Brügger halló 46 casos de amas constituyéndose en madrinas de sus esclavos. Véase Brügger, 2002, 326.

30 Machado, 2006, 73.

31 La ilegitimidad de la población esclava bautizada en El Socorro fue del $62,5 \%$. Véase Salazar, 2017, 112.

32 Los libres de varios colores y los blancos correspondieron al $42,5 \%$ y $50,4 \%$, respectivamente. Véase Tovar, Tovar y Tovar, 1994, 375-376.

33 Salazar, 2017, 83.

34 AHR-UIS, APS, Libro de bautismos de 1766-1781, año 1768, i. 90. 
con antepasados africanos puede indicar su menor número en términos demográficos o el grado de mestizaje que habían conseguido, al punto de confundirse entre la mayoría mestiza. De 153 madrinas socorranas, 22 eran cautivas y 131 , libres $(85,6 \%)$. En 1778 , un esclavo al que nombraron Juan Josef tuvo por madrina a la cautiva Leonarda. La madre del bautizado fue Margarita, que pertenecía a Margarita Arenas ${ }^{35}$ Ahora bien, estos patrones de compadrazgos se asemejan a los presentados en la parroquia de Santa Cruz de San Gil. De los varones que apadrinaron esclavos en esa feligresía, únicamente uno era cautivo y 128 eran libres, esto es, el 99,2\% de los padrinos. De las 87 madrinas, solamente tres eran esclavas, las demás eran mujeres libres $(96,5 \%){ }^{36}$

Llama la atención el hecho de que no hubo indios apadrinando esclavos, lo que indica las pocas relaciones entre ambos grupos en parroquias de españoles, al menos en cuanto al parentesco espiritual, diferente a otros espacios indianos con una amplia presencia indígena en los cuales se dieron estos compadrazgos. ${ }^{37}$ Con todo, hubo bautizos en los cuales los cautivos apadrinaron a los hijos de indígenas, como el mulato Eugenio Plata, que fue padrino de los dos hijos de los indios Pedro Duarte y Basilia Aparicio, llamados Joseph Apolinar y Juana Josepha, respectivamente bautizados en 1769 y 1772..$^{38}$ Tampoco fue destacada la participación de la población de ascendencia africana libre en la configuración de parentescos espirituales con cautivos, con la excepción de los dos mulatos libres indicados anteriormente.

El cuadro 1 resume al detalle las combinaciones de los padrinos y las madrinas de los esclavos. Se constata que las opciones oscilaron entre libres y esclavos, siendo realmente poca la incidencia de los mulatos libres y nula la de la población indígena, como ya se ha indicado. Así pues, se privilegió el vínculo espiritual hombre libre/sin madrina con el 61,3\%. En otros contextos americanos - como Brasil-, los varones libres representaron el $48,4 \%,{ }^{39}$ el $53 \%,{ }^{40}$ el $63 \%,{ }^{41}$ el $70 \%$ y el $90,7 \%{ }^{43}$ de los padrinos de la

35 AHR-UIS, APS, Libro de bautismos de 1766-1781, año 1778, i. 355.

36 Salazar, 2017, 311.

37 O'toole, 2012, 56-57.

38 AHR-UIS, APS, Libro de bautismos de 1766-1781, año 1769, i. 117; año 1772, i. 219.

39 Delfino, 2012, 8.

40 Gómes, 2013, 8.

41 Brügger, 2002, 322.

42 Schwartz, 1995, 332.

43 Cruz, 2006, 89. 
gente cautiva. Este patrón difiere del estudiado para la ciudad de México ${ }^{44}$ y aquellas zonas de grandes plantaciones, ${ }^{45}$ en las cuales el compadrazgo se establecía entre personas de la misma calidad. Las personas libres que apadrinaban a cautivos no conformaban un grupo homogéneo, más aún, algunos gozaron de una posición igual o superior a la de los amos. ${ }^{46}$

\section{CUAdRo 1}

CALIDAD DE LOS PADRINOS Y MADRINAS DE LOS ESCLAVOS BAUTIZADOS
EN LA PARROQUIA DE NUESTRA SEÑORA DEL SOCORRO (1700-1779)

\begin{tabular}{|l|c|c|}
\hline \multicolumn{1}{|c|}{ Padrinos y madrinas } & \multicolumn{2}{c|}{ El Socorro } \\
\hline Hombre libre y sin madrina & 341 & $61,3 \%$ \\
\hline Sin padrino y mujer libre & 82 & $14,7 \%$ \\
\hline Ambos libres & 49 & $8,8 \%$ \\
\hline Sin registro de padrinos & 22 & $3,9 \%$ \\
\hline Sin padrino y madrina esclava & 11 & $2 \%$ \\
\hline Hombre libre y esclava & 3 & $0,5 \%$ \\
\hline Esclavo y sin madrina & 36 & $6,4 \%$ \\
\hline Ambos esclavos & 8 & $1,4 \%$ \\
\hline Mulato libre sin madrina & 2 & $0,3 \%$ \\
\hline Padrino libre y padrino libre & 2 & $0,3 \%$ \\
\hline TotaLEs & 556 & $100 \%$ \\
\hline
\end{tabular}

Fuentes: APS, Parroquia de Nuestra Señora del Socorro, Libro de bautismos de 1699-1738, $i$. 2-447; Libro de bautismos de 1738-1753, i. 1-448; Libro de bautismos de 1753-1765, i. 1-365; Libro de bautismos de 1766-1781, i. 1-388; Libro de bautismos de 1778-1782, i. 1-81 y 249-385.

Así por ejemplo, el 11 de mayo de 1721, Francisco Ambrosio, de un mes de nacido, «hijo de padre incógnito» y de Antonia, esclava de Juan Ortíz de Ávila, recibió el sacramento bautismal. El parentesco espiritual se estableció con Francisco Terán. ${ }^{47}$ Pero, ¿quién era Terán? A pesar de la

44 Gonzalbo, 2005, 215; Masferrer, 2013, 297 y 302.

45 Florentino y Goés, 1997, 92; Florentino y Goés, 2007, 179.

46 Schwartz, 1995, 332.

47 AHR-UIS, APS, Libro de bautismos de 1699-1738, año 1721, i. 120. 
escasa información, es probable que Francisco Terán tuviera nexos cercanos con algunas familias de esclavos porque, además del bautizo referido, en 1716 fue padrino de bodas - junto a la esclava Mónica - de la pareja constituida por el esclavo Miguel y Paula Aguilar. ${ }^{48}$ Además, por una venta de un pedazo de tierra que realizó doña Gabriela Bueno Guerrero a favor de Juan Mejía en 1734, se sabe que Terán tenía un predio en Sancoteo lindando con el bien negociado. ${ }^{49}$

Casos como este revelan que las interacciones que los cautivos tuvieron con los libres se extendían más allá de las dotaciones esclavistas, ya que hubo relaciones que no se circunscribían a lo estrictamente asociado con las labores en las labranzas, en los potreros y en las casas de los amos. Ciertos lugares eran propicios para vincularse con otros cautivos y con gente de otras calidades, como los caminos, los ríos en donde se lavaba la ropa, las entradas de las iglesias y las plazas mayores durante los días de mercado, lo cual supone una interesante movilidad espacial por parte de los cautivos. En otros términos, las oportunidades para relacionarse se debían a la proximidad física entre las esclavonías, las propiedades rurales y los contactos cotidianos entre gente de diversos orígenes y posición social..$^{50}$ Por ejemplo, a finales del siglo XVII, los juegos de naipes y dados involucraban a personas de diferente «estado, calidad y condición», que estaban generando en la parroquia de El Socorro «muchos y graves inconvenientes». De este modo, el 12 de enero de 1698, el alguacil mayor y alcalde ordinario más antiguo de la villa de San Gil y su jurisdicción, el capitán y sargento mayor Joseph Cortés ordenó que:

ninguna persona del estado, calidad o condición que sea, sea osado a tener en sus casas juegos prohibidos de naipes ni dados, ni consentir el que jueguen hijos de familia, criados ni esclavos ni oficiales ni les reciban prendas ni las den sobre ellas cosas ninguna, pena de cien patacones aplicados para obras públicas de esta dicha parroquia [...] asimismo de perder lo que dieren sobre dichas prendas y volverlas a los dueños y juntamente se les manda a todos el que no jueguen a bonos en dichos juegos prohibidos solamente pena por ser causa de donde se originan también muchos perjuicios. ${ }^{51}$

48 AHR-UIS, APS, Libro de matrimonios y defunciones de 1688-1740, año 1716, i. 99.

49 Archivo Notarial de El Socorro (ANS), Notaría Primera de El Socorro, t. 5, año 1734, f. $266 \mathrm{v}-267 \mathrm{v}$.

50 Sirtori y Gil, 2008, 154.

51 Archivo General Municipal de San Gil (AGMSG), Fondo Administración Municipal, c. 1, doc. 16 , año 1698 , f. 15 r. 
Las combinaciones de padres espirituales conformadas por hombre libre/mujer libre y madrina libre/sin padrino también fueron significativas al momento de arreglar compadrazgos. Se observó que luego del vínculo hombre libre/sin madrina, siguió en importancia porcentual el nexo mujer libre/sin padrino. El tercer lugar del orden del apadrinamiento lo constituyó ambos padres espirituales libres. En general, los padrinos y madrinas libres emparentaron con familias de esclavos en la mayoría de los bautizos, pues totalizaron el $84,8 \%$ en El Socorro, mientras que en la vecina feligresía sangileña agruparon el $91,2 \%$ de casos. ${ }^{52}$ De este modo, se revela una predilección de los cautivos por parientes rituales libres, lo que indica una intención por establecer conexiones sociales ventajosas en procura de aliados y protectores. Los progenitores esclavos buscaban compartir la co-paternidad de sus hijos con gente que pudiera disponer de más recursos económicos, una mayor capacidad de movilidad espacial y, a lo mejor, cierto prestigio social. ${ }^{53}$ En estos casos, los esclavos podían contar con los favores de sus compadres y padrinos para sobrellevar el peso de la esclavitud y, como indica Michel Bertrand, los parientes espirituales libres podían servir de mediadores entre el mundo de los esclavos y el de los no esclavos, facilitando el contacto entre las partes. ${ }^{54}$ Compadres y comadres, padrinos y madrinas se constituían en potenciales nodos intermedios para extender las redes de sociabilidad y alcanzar directa o indirectamente a los sectores libres, y quizás, a la gente influyente.

Ahora bien, en relación con los vínculos rituales horizontales, los esclavos de ambos sexos que asumieron el apadrinamiento de los hijos de otros cautivos constituyeron el 1,4\% (ver cuadro 1). Fueron registrados seis padres espirituales como mulatos, cuatro como mulatos esclavos, uno como negro y el resto como esclavos (33). Ocho parejas de cautivos, como por ejemplo, Francisco y Petronila, fueron padrinos de pila de Juana María, hija de Agustina, esclavas del capitán don Salvador Fernández. ${ }^{55}$ Por otra parte, 36 padrinos esclavos aceptaron su papel sin la compañía de una madrina, como el caso del esclavo Marcos, que en 1727 apadrinó a Nicolás, hijo legítimo de los cautivos Jerónimo y María Josepha. ${ }^{56}$ También se presentaron once madres rituales sin padrino, como Feliciana, que en 1762 fue madrina

52 Salazar, 2017, 316.

53 Brügger, 2004, 6 .

54 Bertrand, 2012, 66.

55 AHR-UIS, APS, Libro de bautismos de 1753-1765, año 1759, i. 144

56 AHR-UIS, APS, Libro de bautismos de 1699-1738, año 1727, i. 185. 
de María de la Concepción y comadre de María Antonia, todas ellas esclavas de don Gaspar Álvarez. ${ }^{57}$ Finalmente, fueron tres madrinas cautivas junto a hombres libres los que consolidaron su amistad con sus congéneres por medio del bautizo. Este fue el caso de la mulata Juana María y Toribio Casariego, padrinos de María Rosalía en 1736, «hija de padre no conocido» y de Margarita Marcela, esclava del doctor Francisco de Vergara. ${ }^{58}$

Si bien los padrinos y madrinas de condición cautiva no fueron numerosos, es posible pensar que la opción por los congéneres no obedecía a los escasos auxilios materiales que podían brindar en el diario vivir. Eran otras las ayudas que un cautivo llegaba a recibir de sus padrinos, madrinas, compadres y comadres, como los consejos y el apoyo afectivo que suavizaban las condiciones de la esclavitud. ${ }^{59}$ Igualmente, se debe tener en cuenta el ritual católico como mecanismo para reforzar los lazos de amistad en las poblaciones esclavas, dentro de la unidad esclavista o entre esclavos de amos distintos. ${ }^{60}$ Independientemente de la calidad de los padres espirituales, estos eran admirados y obedecidos por sus ahijados, había un trato con deferencia entre los compadres y ganaban respetabilidad entre los compañeros de cautiverio. ${ }^{61}$ Asimismo, los padrinos y las madrinas asumían una destacada responsabilidad en el cuidado y educación de sus ahijados, especialmente cuando faltaban sus progenitores. ${ }^{62}$ En estas relaciones entre congéneres, es probable que en la selección de esclavos como parientes espirituales se procurara a aquellos que gozaban de cierta ascendencia jerárquica en las propiedades esclavistas, que pudieran brindar algo más que ayuda moral, es decir, cautivos con calificación laboral, autoridad y con mejores posibilidades de contactos sociales con los libres. No obstante, debido a la omisión del oficio de los esclavos registrados en los documentos parroquiales y notariales, no ha sido posible apreciar la trascendencia de este factor. ${ }^{63}$

Como en varios de los documentos bautismales no fueron asentados los nombres de los amos de los esclavos implicados en las ceremonias, los resultados no son concluyentes para descubrir hasta qué grado se configuraron apadrinamientos al interior de las unidades esclavistas. Por el tamaño

57 AHR-UIS, APS, Libro de bautismos de 1753-1765, año 1762, i. 237.

58 AHR-UIS, APS, Libro de bautismos de 1699-1738, año 1736, i. 396.

59 Perera y Meriño, 2006, 59; Cruz, 2006, 92.

60 Machado, 2006, 56.

61 Perera y Meriño, 2006, 59.

62 Brügger, 2004, 8.

63 Slenes, 1997, 271. 
reducido de estas propiedades y la prohibición de la Iglesia de establecer relaciones de casamiento y de concubinato entre parientes espirituales, es posible que los nexos bautismales de los cautivos con sus congéneres se realizaran hacia afuera de su entorno cotidiano.$^{64}$ Así, pocos de los padrinos y de las madrinas pertenecían a las mismas esclavonías de sus ahijados y compadres. Esto refuerza la idea de la capacidad de movilidad y de relacionarse de los cautivos de la comarca, y de la posibilidad de establecer redes sociales de parentesco para cruzar los confines de las propiedades esclavistas.

En El Socorro, hubo trece bautizos en los que padres espirituales y ahijados compartieron los mismos dueños. En esta situación, ejercieron el compadrazgo una pareja de padrino y madrina y, en solitario, dos madrinas y diez padrinos. Estos amos eran ricos, tenían títulos de honorabilidad y ostentaban cargos en la administración política local y en la Iglesia, lo que explicaría que tenían suficientes cautivos para su servicio, entre quienes se establecieron nexos de parentesco espiritual. Sus nombres fueron don Nicolás de Villarreal, doña Catarina González, Pedro Joseph Plata, don Gaspar Álvarez, el doctor don Lorenzo Plata, el doctor don Juan de Bustamante Quijano, el maestro don Nicolás Rodríguez Terán y el doctor don Diego Salvador Cortés. Así, por ejemplo, entre los cautivos de Villarreal, en tres bautizos, el parentesco ritual no salió de la propiedad, sobresaliendo una pareja con dos hijas. Esta fue la situación de Segundo Villarreal y Bernardina que, al bautizar en 1763 a Nicolasa ${ }^{65}$ y en 1767 a María Josepha, ${ }^{66}$ buscaron a los esclavos Lorenzo y Basilio como los padrinos de sus hijas, respectivamente. Asimismo, el 8 de julio de 1762, Pío apadrinó a la recién nacida Lucía Catarina, hija legítima de Pedro Camacho y de Mariana, todos cautivos de Villarreal. ${ }^{67}$

No fue común encontrar desigualdad social entre padrinos y madrinas, que se refiere a la combinación entre esclava y hombre libre (tres casos), que representó el 0,5\%. Por ejemplo, esta fue la situación de Eusebio Cortés y la mulata Luisa Cortés, que apadrinaron en 1719 a la hija de María Ana, negra esclava del doctor don Diego Salvador Cortés, a la que pusieron por nombre Ignacia Francisca.$^{68} \mathrm{La}$ opción de apadrinamiento que

64 Schwartz, 1995, 334

65 AHR-UIS, APS, Libro de bautismos de 1753-1765, año 1763, i. 259.

66 AHR-UIS, APS, Libro de bautismos de 1766-1781, año 1767, i. 63.

67 AHR-UIS, APS, Libro de bautismos de 1753-1765, año 1762, i. 231.

68 AHR-UIS, APS, Libro de bautismos de 1699-1738, año 1719, i. 98. 
compaginaba a un hombre libre con una esclava sería una manera de conciliar la posición social de un protector con los cuidados que una madrina podía prestar en la crianza de los párvulos. ${ }^{69}$ Sin embargo, no fue común hallar esta combinación en El Socorro, a diferencia de los casos observados en Minas Gerais, con el 4,2 \%, ${ }^{70}$ y Curitiba, con el $10 \% .^{71}$

La información que poseen los libros de bautismos de El Socorro es insuficiente para establecer con qué grado fueron seleccionados los propios familiares para el parentesco espiritual. No es posible conocer si entre los padrinos se reforzaron lazos con los tíos, primos y abuelos de los bautizados, tema estudiado por otros investigadores. ${ }^{72}$ Parece ser que, en el curato analizado, los esclavos prefirieron escoger la ampliación de su propia red de relaciones sociales más allá de sus parentelas y de las unidades esclavistas, para establecer nuevos nexos parentales por medio del bautizo, en lugar de reforzar los vínculos familiares.

Ahora bien, ¿cómo fueron configurados los nexos espirituales de los hijos de esclavos varones y mujeres libres? A pesar de que el progenitor era cautivo, la condición de estos bautizados era heredada de la madre, es decir, nacían libres. El cuadro 2 muestra que las inclinaciones de estos progenitores por los libres fueron más marcadas que en los párvulos nacidos cautivos, con el 94,7\%. Únicamente cuatro padrinos y una madrina fueron esclavos, constituyendo el 5,3\% de los 95 casos considerados. Así pues, en 1776 Micaela, esclava del cura doctor don Francisco de Vargas, fue la madrina de María Antonia, hija de Pedro, esclavo del referido padre Vargas. ${ }^{73}$ A su vez, el 18 de octubre de 1767, un niño de 5 días de nacido, al que pusieron por nombre Eduardo Joseph, fue apadrinado por el esclavo Felipe, de propiedad de Ventura Pereira. Los progenitores de la criatura bautizada fueron Rufina, libre, y Julián, cautivo de Juan Bernardo Villegas. ${ }^{74}$ Se debe destacar que, además de estos padres rituales esclavos, hubo un padrino inscrito como «criado del señor cura», llamado Carlos, quien en 1777 fue padrino de Juan Eusebio, hijo legítimo de Ana Francisca Estévez y de Juan, cautivo de don Antonio García. ${ }^{75}$

69 Gómes, 2013, 8; Brügger, 2004, 7.

70 Delfino, 2012, 8.

71 Schwartz, 1992, 149.

72 Alfani, 2008, 97-98; Brügger, 2002, 352-353 y 357; Perera y Meriño, 2006, 66-67.

73 AHR-UIS, APS, Libro de bautismos de 1766-1781, año 1776, i. 299.

74 AHR-UIS, APS, Libro de bautismos de 1766-1781, año 1767, i. 74.

75 AHR-UIS, APS, Libro de bautismos de 1766-1781, año 1777, i. 312. 


\section{Cuadro 2}

CALIDAD DE LOS PADRINOS Y MADRINAS DE HIJOS DE ESCLAVOS Y MUJERES LIBRES BAUTIZADOS EN LA PARROQUIA DE NUESTRA SEÑORA DEL SOCORRO (1700-1779)

\begin{tabular}{|l|c|c|}
\hline & \multicolumn{2}{c|}{ El Socorro } \\
\hline \multicolumn{1}{|c|}{ Padrinos y madrinas } & Cantidad & Porcentaje \\
\hline Hombre libre y sin madrina & 64 & $67,3 \%$ \\
\hline Ambos libres & 11 & $11,5 \%$ \\
\hline Sin padrino y mujer libre & 14 & $14,7 \%$ \\
\hline Sin padrino y madrina esclava & 1 & $1,1 \%$ \\
\hline Padrino «criado de» y sin madrina & 1 & $1,1 \%$ \\
\hline Esclavo y sin madrina & 4 & $4,2 \%$ \\
\hline ToTALES & 95 & $100 \%$ \\
\hline
\end{tabular}

Fuentes: APS, Parroquia de Nuestra Señora del Socorro, Libro de bautismos de 1699-1738, i. 2-447; Libro de bautismos de 1738-1753, i. 1-448; Libro de bautismos de 1753-1765, i. 1-365; Libro de bautismos de 1766-1781, i. 1-388; Libro de bautismos de 1778-1782, i. 1-81 y 249-385.

Los demás niños tuvieron como padrinos y madrinas a personas libres. Dos terceras partes de los párvulos fueron bautizados únicamente en compañía de los padrinos, como cuando el 28 de marzo de 1717 fue consagrada Rufina, cuyo padre espiritual fue Cristóbal de Meza. La niña era hija legítima del esclavo Salvador y de Catarina de Aguilar. ${ }^{76}$ Las mujeres libres sin padrino también estuvieron presentes como madres rituales $(14,7 \%)$, como fue el caso de Margarita Matamoros, al ser madrina en 1728 de Juana Josepha. Los padres de la bautizada eran el esclavo Teodor y María, la cual fue registrada sin su apellido ni su calidad. ${ }^{77}$ El 11,5\% de los hijos de esclavos con mujeres libres tuvieron ambos padrinos, como, por ejemplo, la niña llamada Juana María, hija legítima de Juan, esclavo del capitán Buenaventura de Uribe, y de Josepha, sirviente libre del mismo vecino. El 16 de agosto de 1739, Buenaventura de Lamos y María de Lamos llegaron a ser los padres espirituales de Juana María. Se desconoce si entre los padrinos mediaba algún lazo de parentesco. ${ }^{78}$

76 AHR-UIS, APS, Libro de bautismos de 1699-1738, año 1717, i. 59.

77 AHR-UIS, APS, Libro de bautismos de 1699-1738, año 1728, i. 201.

78 AHR-UIS, APS, Libro de bautismos de 1738-1753, año 1739, i. 14 


\section{Ahijados esclavos de padrinos y madrinas de alcurnia: Compadrazgos exitosos}

Algunos cautivos lograron establecer nexos con personas de influencia social y política en la comarca, es decir, con hombres y mujeres que tenían un tratamiento especial de «don» y «doña», con quienes ejercían cargos en la Iglesia y con poseedores de títulos militares, por ende, vecinos enraizados en la zona que ostentaban riquezas y una posición privilegiada. Sin embargo, el parentesco espiritual no anulaba las distancias de las jerarquías sociales, a pesar de que simbólicamente creaba un nexo como iguales entre los compadres, sino que acercaba a personas desiguales mediante el bautizo de un descendiente, pasando a reconocerse como parientes. ${ }^{79} \mathrm{El}$ apadrinamiento de esclavos por gente de alcurnia evidencia la práctica del padrinazgo con el fin de establecer contactos en todos los niveles de la sociedad, asociando personas y familias. ${ }^{80}$ En el caso específico del parentesco ritual forjado entre cautivos y esta categoría de personas implicaba relaciones verticales marcadas con deberes de amistad, cooperación y reciprocidad alrededor del bautizado. Los esclavos que lograban crear este tipo de asociaciones tenían la expectativa de granjearse protección, favores y auxilios que podían conseguir de sus parientes espirituales a lo largo de su existencia, aun cuando sean difíciles de rastrear huellas mediante la documentación de archivo. Desde otro ángulo, estos compadres y ahijados esclavos se ubicaban como intermediarios entre sus compañeros de cautiverio y los grupos privilegiados, como lo ha sugerido Renato Pinto Venâncio ${ }^{81}$ En últimas, afloraba una amplia variedad de sentimientos de afecto, de confianza y de intereses entre los implicados en el bautizo. ${ }^{82}$

En la parroquia de Nuestra Señora del Socorro, doce hombres que ostentaban el título de «don» asumieron el apadrinamiento de esclavos ( $2,7 \%$ de los padres espirituales). En lo concerniente a las «doñas», dos se desempeñaron como madrinas, es decir, el 1,3\%, una de las cuales sin la compañía del padrino. Así pues, en 1708 doña Tomasa de Luna fue madrina del esclavo Juan, hijo de «padres no conocidos» y a quien no se le asentó el nombre de su amo. ${ }^{83} \mathrm{~A}$ su vez, once de los hombres inscritos como «don»

79 Brügger, 2002, 358 y 366; Nacif, 2014, 71.

80 Alfani, 2008, 104.

81 Venâncio, 2003, 606.

82 Brügger, 2002, 365.

83 AHR-UIS, APS, Libro de bautismos de 1778-1782, año 1708, i. 259. 
apadrinaron individualmente. Por otra parte, entre los párvulos nacidos de esclavos y mujeres libres, ninguna persona registrada como «don» $\mathrm{O}$ «doña» asumió el padrinazgo.

Otros padrinos de renombre local fueron ocho eclesiásticos.$^{84}$ Solo a dos se les omitió la etiqueta de «don», fueron el padre Sebastián José Pereira y el clérigo Francisco Gonzalo de Rueda. En 1713, Pereira apadrinó a un recién nacido llamado Vicente Ferrer, esclavo del doctor don Juan de Bustamante Quijano. El asiento bautismal no dejó constancia de los nombres de los progenitores del párvulo. ${ }^{85}$ Es posible que la influencia del doctor Bustamante pesara en la selección del padre Sebastián como padrino de Vicente, más aún ante la ausencia de los progenitores del bautizado. En casos como estos, los esclavos esperaban favorecerse del prestigio sociopolítico y de los auxilios materiales de los clérigos, más aún, del amparo espiritual y la mediación directa con la corte celestial que ningún otro ser humano, sino los sacerdotes, podía ejercer. ${ }^{86}$ En estas sociedades con fuertes creencias, el prestigio social y religioso que tenían los padrinos eclesiásticos se vinculaba con la protección sobrenatural que podía repeler fuerzas espirituales enemigas de Dios. Además, proveniente de la administración de la Iglesia, un notario eclesiástico llamado Juan Rodríguez Malpica, ejerció como padrino en 1710, de quien se hablará más adelante.

Otros padres espirituales con una destacada reputación social, económica y política fueron los que ostentaban títulos militares: un capitán (Francisco Arias de Toledo), dos sargentos (Dionisio García de Cabrera y Juan de Ardila) y un ayudante (Mateo Ortíz Galeano). ${ }^{87}$ De los padrinos de esclavos que poseían cargos en la administración político-judicial local se encontraron en la feligresía de San Gil, un alférez real (don Francisco Suárez) y un alguacil mayor (Pedro Gómez Currea) ${ }^{88}$ En 1740, Ana María de 14 años, esclava de Francisca de Ardila, tuvo por padrino al sargento Juan de Ardila. ${ }^{89}$ En el asiento no fue registrado el nombre de sus progenitores, ni la relación existente entre la dueña y el padrino de Ana María, aunque es

84 Estudios como los de Delfino, Renato Pinto y Brügger muestran la existencia de casos en que los padrinos de los párvulos fueron reconocidos como santos y vírgenes, véase Delfino, 2012, 7; Venâncio, Sousa y Pereira, 2006, 276; Brügger, 2002, 330.

85 AHR-UIS, APS, Libro de bautismos de 1778-1782, año 1713, i. 332.

86 Brügger, 2002, 342.

87 Según el Diccionario de Autoridades de 1726, el ayudante era un empleo militar con diferentes grados y títulos que asistía a los ayuntamientos, generales, maestres de campo y mariscales, cuyas funciones eran distribuir las órdenes a los soldados y formar los escuadrones.

88 Salazar, 2017, 325.

89 AHR-UIS, APS, Libro de bautismos de 1738-1753, año 1740, i. 29. 
posible sospechar el parentesco entre ambos porque llevan el mismo apellido. Casos como estos evidencian que si los amos no apadrinaban a sus esclavos, esta función la asumían sus parientes o amigos. ${ }^{90}$

Los compadres de abolengo representaban la consolidación de la extensión de las redes sociales de los cautivos, de quienes esperaban fidelidad y servicios, constituyéndose en un potencial capital político. ${ }^{91}$ Tras estos vínculos rituales, sin duda, estaban los intereses de los propietarios, en el sentido de que los compadres de sus esclavos eran del mismo nivel social o superior - tal vez un familiar o un amigo- $y$, directa o indirectamente, se aseguraban para sí mismos el sometimiento y obediencia de sus cautivos. También es posible suponer que algunos amos usaban el bautismo de sus esclavos con la misma intención de los bautizos de su descendencia, es decir, para crear o fortalecer sus propios nexos sociales con otros miembros de las familias prestantes. ${ }^{92}$ De este modo, en casos como estos, es probable argumentar la intervención de los dueños en la elección de padrinos de alcurnia para sus cautivos, de lo cual todas las partes vinculadas sacaban algún provecho: compadres, ahijados, esclavos y amos.

Algunos padrinos defendieron a sus ahijados o compadres en las cortes judiciales ${ }^{93} \mathrm{o}$ ante los propietarios; ${ }^{94}$ otros procuraron su libertad pagando por ella. ${ }^{95} \mathrm{El}$ caso que sirve para mostrar la situación planteada es el de la mulata liberta Juana Felipa (aunque no es particularmente de El Socorro, sino de una parroquia vecina). Luego de diez años de gozar de su libertad, obtenida mediante carta de manumisión otorgada por su amo el 17 de diciembre de 1750, fue reducida a esclavitud por los herederos de este: doña Bernabela de Rueda, Andrea Martínez Ramírez y Francisco Antonio de Rojas. En el pleito judicial intervinieron en favor de la afectada don Luciano de Rueda y el cura de Simacota, el doctor don Marcelino Rangel. A pesar de que en el expediente no menciona la existencia de algún nexo de parentesco o compadrazgo entre Juana Felipa, su marido Mateo Toledo, «color pardo», don Luciano de Rueda y el doctor Rangel, es posible sospechar que entre las partes se tejieron lazos de amistad que los unieron y que les permitieron cooperar para defender la libertad de la mulata y la de sus hijas, Ana Joaquina y María Gertrudis. La mediación del cura de Simacota sugiere que los

90 Proctor III, 2001, 245; Gómes, 2013, 15.

91 Venâncio, Sousa y Pereira, 2006, 274; Brügger, 2003, 7.

92 Proctor III, 2001, 248; Perera y Meriño, 2006, 62.

93 Barcia, 2003, 119.

94 Schwartz, 1995, 332

95 Masferrer, 2013, 294; Maia, 2010, 48. 
esclavos y ex esclavos que tuvieron el apoyo de personas de prestigio pudieron defenderse con éxito de quienes intentaron vulnerar sus concesiones y derechos. Así pues, en Santafé, a 25 de mayo de 1762, casi dos años después de iniciado el proceso, la Audiencia determinó que, «por lo que resulta de la escritura de libertad presentada por Juana Felipa se le ampara a esta y a sus hijos en la que han estado y ninguna persona de cualquier condición o calidad que sea no le inquietara pena de doscientos pesos». ${ }^{96}$

\section{Los compadres de Ciprián, Petrona y Josepha. El caso de los esclavos del doctor Cortés}

El doctor don Diego Salvador Cortés era uno de los sacerdotes más adinerados de El Socorro y de la jurisdicción de la villa de San Gil, dueño de tierras en varios sitios de la comarca (como Sancoteo, Caraota, Quebrada Honda, Las Porqueras, Piedra del Sol y Pinchote), incluyendo la hacienda de Las Culas que heredó de su tío, el capitán y sargento mayor Joseph Cortés. ${ }^{97}$ Entre 1713 y 1732, el doctor Cortés adquirió once esclavos ${ }^{98}$ y vendió uno. ${ }^{99}$ Estos reprodujeron de manera sobresaliente, dado el número de los consagrados en la pila bautismal de El Socorro. De 1710 a 1736, fueron bautizados 27 párvulos, hijos de doce esclavas y de un cautivo, apadrinados por dos esclavos y una esclava - fuera de los padrinos y madrinas libres-, para un total de 43 cautivos del padre Cortés. El día 8 de julio de 1736, el doctor Cortés fue registrado en el libro de difuntos de aquella parroquia sin haber hecho su testamento, ${ }^{100}$ por lo que no se cuenta con la valiosa información que permitiría conocer con mayor detalle la dimensión de su patrimonio.

Ahora bien, doce varones y quince mujeres constituyeron los esclavos bautizados de este presbítero. A diez de estos se les anotó su rango generacional, siendo nueve mulatos y un negro; a su vez, de las madres

96 Archivo General de la Nación de Colombia (AGN), Sección Colonia, Fondo Negros y Esclavos de Santander, t. 4, año 1750, f. 198v.

97 AGMSG, Fondo notarial, paq. 4, doc. 77, año 1705, f. 2r-v; Salazar, 2011, 133.

98 AGMSG, Fondo notarial, paq. 3, doc. 112, año 1714, f. 60r-61v; paq. 5, doc. 166, año 1717 , f. 8r-10v. ANS, Notaría Primera de El Socorro, t. 2, año 1713, f. 117v-118v; año 1715, f. 413r-414v; año 1716 , f. 183v-185v; año 1716, f. 173r-174v; año 1719, f. 617r-619v; año, 1719, f. 595v-597v; t. 3, año 1720 , f. 48r-50v; t. 4, año 1732 , f. 556v-558v.

99 ANS, Notaría Primera de El Socorro, t. 2, año 1718, f. 303v-305r.

100 AHR-UIS, APS, Libro de defunciones de 1722-1771, r. 1855276, i. 15, año 1736, f. 54v. 
registradas, doce fueron mulatas y siete negras. Asimismo, solamente tres eran hijos legítimos, seis de ambos padres no conocidos y, el resto, fueron bautizados por sus progenitoras. Es decir, las madres estuvieron presentes en 21 de los 27 bautizados, mientras que los padres solo lo fueron en tres casos (este fue el mismo progenitor, Ciprián Pimentel, al que se aludirá más adelante). Esto último muestra que en esta propiedad esclavista, a pesar de los numerosos esclavos, tres cuartas partes de los infantes estaban amparados únicamente por sus madres, lo que indica la tendencia de la matrifocalidad e ilegitimidad de nacimiento predominantes entre los cautivos de la feligresía socorrana.

¿Con qué tipo de gente emparentaron los esclavos del doctor don Diego Salvador Cortés mediante el sacramento del bautismo? Del análisis de los padres espirituales, se puede ver que, en 1723, dicho sacerdote apadrinó a dos de sus esclavos, Juana Antonia y Nicolás, hijos de las mulatas esclavas Alejandrina y Juana Sabina, respectivamente. ${ }^{101}$ Otros de los padrinos con preeminencia local fueron el sargento Dionisio García de Cabrera, ${ }^{102}$ el clérigo Francisco Gonzalo de Rueda ${ }^{103}$ y el citado Juan Rodríguez de Malpica, notario eclesiástico. ${ }^{104}$ Siguiendo con el estudio de los padrinos libres, que revela la heterogeneidad social del apadrinamiento de los cautivos, hubo dieciocho padres espirituales no esclavizados, aparte de los arriba mencionados, de los cuales, seis estuvieron acompañados por mujeres. Se desconoce quiénes estaban unidos por el vínculo matrimonial —o cualquier otro enlace de parentesco_- dada la ausencia de la expresión «su mujer».

Es interesante resaltar entre los padrinos libres a dos pequeños propietarios rurales, uno de ellos dueño de algunos esclavos. El primero fue Marcos Fernández Feo, poseedor de — al menos — un pedazo de tierra, la octava parte de media estancia ${ }^{105}$ en el sitio de la quebrada de Guayacán, la cual había adquirido en 1716 por la suma de 150 pesos. ${ }^{106}$ Asimismo, entre 1719 y 1725 , compró seis esclavos ${ }^{107}$ y vendió cuatro. ${ }^{108}$ El segundo de los

101 AHR-UIS, APS, Libro de bautismos de 1699-1738, año 1723, i. 140.

102 AHR-UIS, APS, Libro de bautismos de 1699-1738, año 1720, i. 106.

103 AHR-UIS, APS, Libro de bautismos de 1699-1738, año 1719, i. 97.

104 AHR-UIS, APS, Libro de bautismos de 1778-1782, año 1710, i. 287.

105 Aproximadamente, de 19 a 20 hectáreas, teniendo en cuenta que una estancia comprendía unas 319,5 hectáreas.

106 ANS, Notaría Primera de El Socorro, t. 2, año 1716, f. 141r-142r.

107 ANS, Notaría Primera de El Socorro, t. 2, año 1719, f. 519r-520r; t. 3, año 1721, f. 114r-v; año 1722, f. 275r-276r; f. 336v-337v; año 1725, f. 515r-v.

108 ANS, Notaría Primera de El Socorro, t. 3, año 1720, f. 40r-41r; año 1725, f. 509v-510v; f. $510 \mathrm{v}-511 \mathrm{v} ;$ f. $527 \mathrm{r}-528 \mathrm{r}$. 
padrinos libres fue Juan de Vega, dueño de dos predios rurales, uno en el sitio de los Uvos ${ }^{109}$ y otro en El Bosque. ${ }^{110}$

Finalmente, seis cautivos (cinco mulatos y uno registrado simplemente como «esclavo») apadrinaron a los esclavos del doctor Cortés, de los cuales dos fueron registrados explícitamente como parte de aquella propiedad esclavista. Cuatro de estos padrinos tuvieron la compañía de las madrinas correspondientes —igualmente esclavas-, desconociéndose si estaban casados, mientras los otros dos apadrinaron a sus ahijados con ausencia de la madrina. Con todo, estos bautizos muestran cómo se establecían las alianzas en algunas unidades esclavistas y entre esclavos de distintos dueños.

Ahora bien, de los 27 cautivos bautizados, únicamente diez tuvieron madrina, todas ellas junto con el padrino. Fueron seis esclavas, una doña y tres sin registro de la calidad, es decir, cuatro mujeres libres. La más destacada fue doña María Magdalena de Cárdenas, esposa de Joseph Hernández Zambrano, con quien apadrinó en 1730 a María Gertrudis, hija de la mulata esclava Francisca. ${ }^{111}$ Las otras tres madres espirituales libres fueron Jacinta Lombana (junto a Joseph Cortés), Agustina Moreno (con Juan Joseph Ballesteros) y Juana Mayorga (con Jacinto Patiño). Las seis madrinas esclavas revelan la consolidación de lazos de parentesco espiritual horizontales, especialmente en aquellos bautizos en los que ambos padres espirituales compartían la condición esclava de sus comadres y ahijados. Por ejemplo, el caso de la mulata Marcela y Ambrosio de Rueda, que apadrinaron a la mulata esclava Antonia del Espíritu Santo, hija de «padre no conocido» y de la negra esclava Josepha. El sacramento se realizó el 2 de septiembre de 1710, siendo impartido por el doctor don Diego Salvador Cortés, cura interino de la parroquia de El Socorro. ${ }^{12}$ En este nexo espiritual se revela un vínculo horizontal con la madrina y otro vertical con el padrino: Con la primera, con quien se compartía la condición de esclava, se aseguraba la asistencia y el apoyo moral y, con el segundo, se proveía de una apertura al mundo de los libres y, tal vez, a cierta ayuda material.

Para concluir, centraremos nuestra atención en la reconstrucción de las relaciones de compadrazgo de una pareja de casados y de una madre soltera, cada uno con tres hijos. El primer caso se trató de Ciprián Pimentel

109 ANS, Notaría Primera de El Socorro, t. 2, año 1718, f. 316v-317v.

110 ANS, Notaría Primera de El Socorro, t. 3, año 1725, f. 560r-561v.

111 AHR-UIS, APS, Libro de bautismos de 1699-1738, año 1730, i. 239.

112 AHR-UIS, APS, Libro de bautismos de 1778-1782, año 1710, i. 287. 
Cortés, mulato esclavo, y Petrona Cortés, negra esclava, quienes se unieron en matrimonio en la iglesia parroquial de El Socorro el 22 de octubre de $1710 .{ }^{113}$ En 1716 nació su hijo Juan Francisco, bautizado el 20 de septiembre de 1719, cuando tenía 3 años y 4 meses de edad. Fueron sus padrinos los mulatos esclavos Francisco Cortés y Lucía. ${ }^{114} \mathrm{Al}$ año siguiente, el 13 de junio de 1720, Margarita Marcela, de 11 meses y 7 días, y Agustín — de edad desconocida - recibieron el bautizo de manos del maestro don Martín Carlos Gómez de Velandia, teniente de cura de El Socorro, quien había cristianizado a su hermano el año anterior. Margarita fue apadrinada por los mulatos esclavos Ambrosio e Inés, mientras que Agustín lo fue por Joseph Cortés y Jacinta Lombana (ver gráfico 1). ${ }^{115}$

Respecto de la trayectoria de esta familia de esclavos, es interesante señalar algunos aspectos. Ciprián Pimentel Cortés fue registrado en el asiento matrimonial como «mulato esclavo», pero en los bautizos de sus tres hijos fue inscrito como «negro esclavo», lo que revela que la calidad no era una categoría estática, sino que se transformaba según la documentación que se producía con los años. Por otra parte, su mujer, Petrona (como aparece registrada en el acta de matrimonio), si bien fue inscrita como negra en los cuatro asientos parroquiales, en los bautizos de sus vástagos fue nombrada como Petronila. Asimismo, únicamente en el bautizo del primer hijo, Petrona fue registrada con su apellido, mientras que en los demás careció de este dato, al igual que su marido. Información como el nombre, el apellido y la calidad constituyen las mayores dificultades para reconstruir la vida de una parentela esclava, aunque en este caso se conoce el nombre del amo como dato para identificar el grupo doméstico en cuestión. Además, los tres hijos fueron registrados sin calidad ni condición, a pesar de que esta información manifestaba su pertenencia al doctor Cortés. Sin duda, bastaban los datos de la madre para ubicar la posición social de los cautivos.

En lo que respecta al apadrinamiento de los hijos de Ciprián y Petrona, los tres contaron con padrinos y madrinas, desconociéndose si estos estaban casados. Las alianzas bautismales establecidas por Ciprián y Petrona fueron en dos ocasiones horizontales y en una vertical. Los mulatos esclavos Francisco Cortés y Lucía fueron escogidos como padrinos de Juan Francisco, y los mulatos esclavos Ambrosio e Inés para Margarita Marcela. Sus apellidos y los nombres de sus amos fueron omitidos en los registros,

113 AHR-UIS, APS, Libro de matrimonios y defunciones de 1688-1740, año 1710, i. 73.

114 AHR-UIS, APS, Libro de bautismos de 1699-1738, año 1719, i. 98.

115 AHR-UIS, APS, Libro de bautismos de 1699-1738, año 1720, i. 105. 
información que resulta clave para ubicarlos en una unidad esclavista. Es posible que Francisco Cortés perteneciera al doctor Cortés dado que llevaba el mismo apellido que los progenitores de su ahijado y de su dueño. Estos enlaces, si bien no garantizaban asociaciones con personas situadas en un escalón social más elevado, sí consolidaban amistades y solidaridades forjadas con quienes se compartía la situación de esclavitud.

De los tres hijos de Ciprián y Petrona, solamente Agustín fue apadrinado por una pareja de libres, Joseph Cortés y Jacinta Lombana. Los datos son insuficientes para constar que este padrino se tratara del exesclavo del sargento mayor Joseph Cortés. De la madrina no se cuenta con información adicional en otros fondos documentales. Lo que se ve en el nexo con gente libre es que los padres de Agustín buscaban un enlace social hacia arriba, que les garantizara protección para su hijo, y para sí mismos, a través de un vínculo ritual con personas que tuvieran más recursos materiales y una posición social de mayor privilegio que la suya.

El segundo caso es el apadrinamiento de las tres hijas de la negra esclava Josepha, quien no estuvo acompañada por ningún cónyuge en esos bautizos (ver gráfico 2). Conforme se puede observar en la documentación notarial, esta cautiva no apareció entre los esclavos negociados por el doctor Cortés, lo que indicaría que nació en su casa, fue heredada o, a lo mejor, fue adquirida en otra comarca en la que se realizó el protocolo de compraventa y que permaneció en la unidad esclavista durante la vida de su amo. El 2 de septiembre de 1710 fueron bautizadas sus dos primeras hijas en una ceremonia: la negra esclava Petronila — nacida en 1706, de tres años y medio- y Antonia del Espíritu Santo, mulata esclava, de tres meses. Para la hija mayor, Josepha buscó como padrino al referido notario eclesiástico del curato de El Socorro, Juan Rodríguez de Malpica, quien ejerció el oficio al menos desde 1710 a $1721 .{ }^{116}$ Este estaba casado con Ana de Uribe y Lamo, como se observa en el bautizo de su hijo Tomás Joseph. ${ }^{117}$ Los padrinos de la segunda niña fueron Ambrosio de Rueda y la mulata Marcela, ${ }^{118} \mathrm{de}$ quienes se desconoce si estaban casados, y si la esclava formaba parte de la propiedad del doctor Cortés. En 1712 nació Feliciana, tercera hija de Josepha, quien fue bautizada el 17 de septiembre de 1719 cuando tenía siete

116 AHR-UIS, APS, Libro de matrimonios y defunciones de 1688-1740, año 1710, i. 70. AHR-UIS, APS, Libro de bautismos de 1699-1738, año 1721, i. 120.

117 AHR-UIS, APS, Libro de bautismos de 1699-1738, año 1702, i. 15.

118 APS, Parroquia de Nuestra Señora del Socorro, Libro de matrimonios y defunciones de 1688-1740, año 1710, i. 287. 


\section{GRÁFICO 1}

\section{APADRINAMIENTO DE LOS HIJOS DE CIPRIÁN PIMENTEL CORTÉS Y PETRONA CORTÉS, 1719-1720}

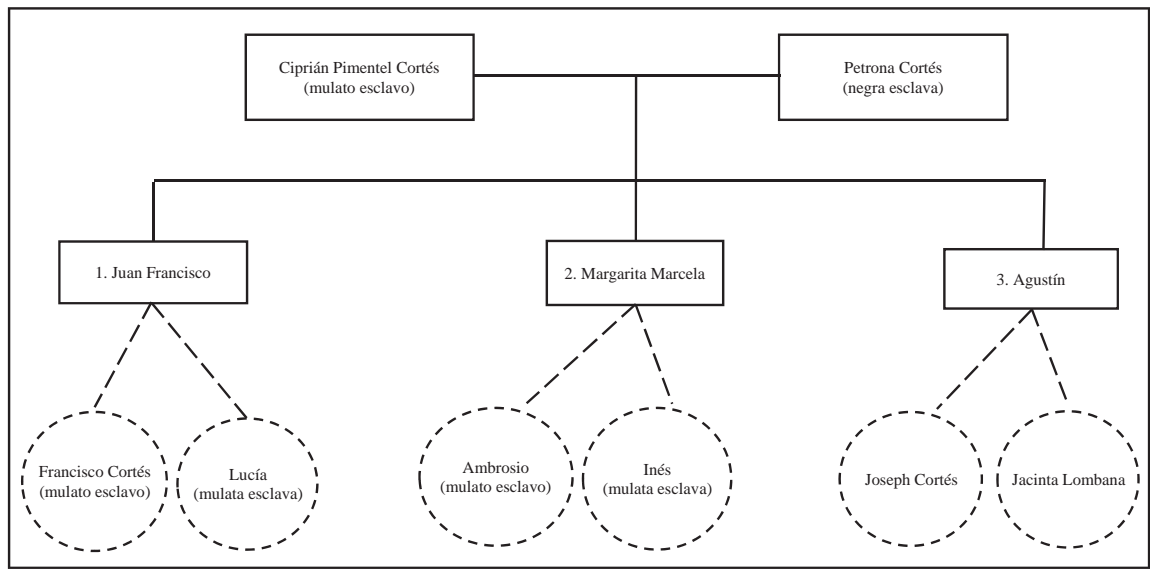

Fuentes: APS, Parroquia de Nuestra Señora del Socorro, Libro de bautismos de 1699-1738, años 1719 y 1720 , i. 98 y 105.

\section{GRÁFICO 2}

APADRINAMIENTO DE LOS HIJOS DE JOSEPHA, 1710-1719

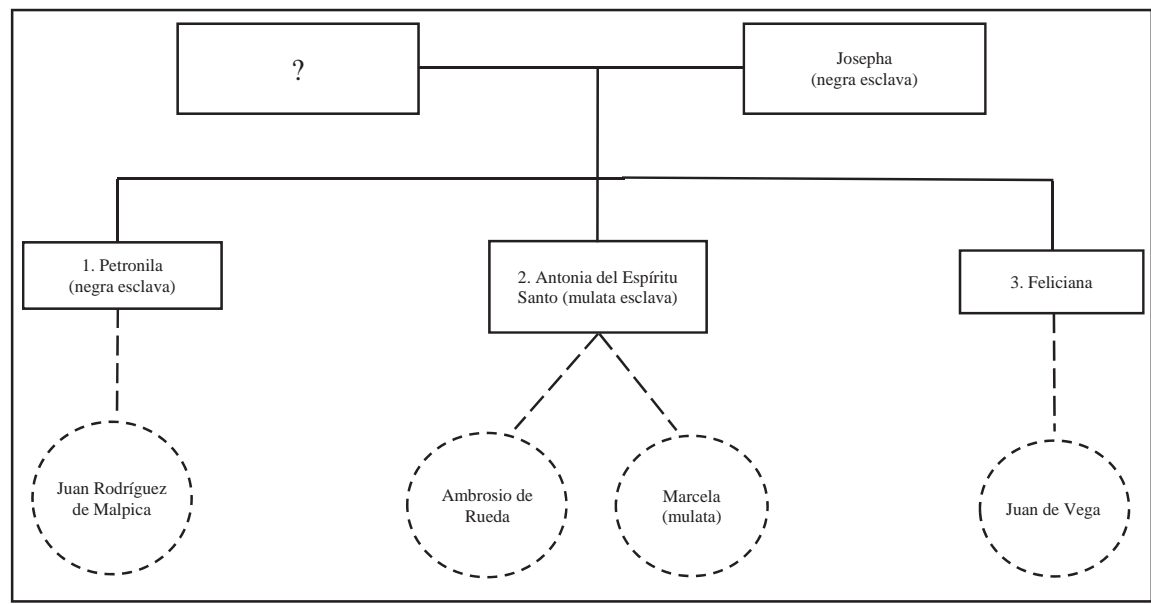

Fuentes: APS, Parroquia de Nuestra Señora del Socorro, Libro de bautismos de 1778-1782, año 1710, i. 287; Libro de bautismos de 1699-1738, año 1719, i. 97. 
años y tres meses. En esta ocasión, Juan de Vega fue seleccionado para apadrinar a la niña. ${ }^{119}$

Las asociaciones de apadrinamiento que Josepha estableció para su prole muestran que, a diferencia del caso anterior, se privilegiaron las relaciones verticales, dado que de los tres padrinos y una madrina, se vinculó con tres hombres libres y una esclava. Casos como estos revelan que algunas esclavas solteras buscaban gente no esclavizada como protectores y tutores de sus hijos, especialmente hombres con capacidades morales y materiales que pudieran asumir responsabilidades de «padres» $\mathrm{o}$ «com-padres», a falta del progenitor. Asimismo, el caso de los bautizos de las hijas de Josepha muestra cómo el nacimiento de los hijos era aprovechado por las madres solteras para fortalecer relaciones sociales con personas no esclavizadas y extender su rango de acción más allá de la unidad esclavista a la que pertenecía. De esta manera, quedaban constituidos los puentes - en este caso, mediante los bautizos de las tres hijas - para acceder al mundo de los libres.

\section{Conclusiones}

Este artículo exploró la configuración y peculiaridades de los tejidos sociales y los alcances de las redes en las que estuvieron inmersos los cautivos bautizados y sus progenitores en el curato de El Socorro. Las figuras de padrino, madrina, compadre, comadre y ahijado establecidas desde la cultura religiosa se constituyeron en elementos indispensables para dinamizar las amistades de la gente de distintas calidades en los reinos hispánicos de ultramar. La concurrencia de progenitores y padres espirituales prueba la existencia de los vínculos estrechos que unieron a esclavos, «libres de varios colores», gente de alcurnia e indígenas — mucho menos estos últimos- . Se ha mostrado que las redes de parentesco no solamente se reducían a los lazos consanguíneos, a los parientes de los cónyuges o a la misma situación socioeconómica, sino que los alcances desbordaron el parentesco y la unidad esclavista, incorporando los círculos sociales de confidentes y amigos de diversos orígenes socio-étnicos.

De hecho, fue destacable la activa participación de padrinos y madrinas libres en los bautizos de los esclavos, lo que muestra la capacidad

119 APS, Parroquia de Nuestra Señora del Socorro, Libro de bautismos de 1699-1738, año 1719 , i. 97 
de sus progenitores para relacionarse más allá de los contornos del mundo de la esclavitud, buscando acceder a otro tipo de recursos - económicos, sociales, políticos y espirituales-, que estaban limitados para sus congéneres. Se prefirieron a los libres, y no a los parientes y a otros esclavos. Resultó evidente que el tamaño reducido de la unidad esclavista restringió la estructuración de parentescos rituales entre cautivos, lo que favoreció una activa red de relaciones de compadrazgos que complementó los lazos consanguíneos y matrimoniales. La vida de los esclavos de la parroquia de El Socorro era dinámica y con una apertura social al mundo de los libres que les permitió intercambiar experiencias, recursos materiales y vincularse más ampliamente a la sociedad hasta donde los amos lo permitieron.

Recibido el 19 de enero de 2018 Aceptado el 6 de abril de 2018

\section{Referencias bibliográficas}

Alfani, Guido, «La Iglesia y el padrinazgo: ¿una institución social rebelde? (Italia, España y Europa desde el siglo V hasta la actualidad)», Revista de Demografía Histórica, XXVI, 1, Madrid, 2008, 87-124.

Aprile-Gniset, Jacques, La ciudad colombiana: prehispánica, de conquista e indiana, Bogotá, Banco Popular, 1991.

Barcia Zequeira, María del Carmen, La otra familia: Parientes, redes y descendencia de los esclavos en Cuba, La Habana, Casa Editorial de Las Américas, 2003.

Bertrand, Michel, «De la familia a la red de sociabilidad», Páginas. Revista digital de la Escuela de Historia, 4, 6, Rosario, 2012, 47-80. Disponible en http:// revistapaginas.unr.edu.ar/index.php/RevPaginas/article/view/94/94 [Consultado:18/01/2018].

Brügger, Silvia María Jardim, Minas patriarcal - família e sociedade (São João del Rei, século XVIII e XIX), Tesis doctoral dirigida por la Dra. Sheila Siquieria de Castro Faria. Universidade Federal Fluminense, Departamento de Histórica, 2002. Disponible en https://app.uff.br/pergamum/catalogo/biblioteca/ index.php [Consultado: 14/01/2018]

Brügger, Silvia Maria Jardim, «Padrinhos de Muitos Afilhados: um estudo do significado do compadrio em São João del Rei, Séculos XVIII e XIX», Anais do XXII Simpósio Nacional de História: História, acontecimento e narrativa (Anais ANPUH-XXII), João Pessoa, Brasil, ANPUH, 2003, 1-8. CD-ROM. Disponible en http://anais.anpuh.org/wp-content/uploads/mp/pdf/ANPUH. S22.635.pdf [Consultado: 13/09/2016]. 
Brügger, Silvia Maria Jardim, «Compadrio e escravidão: uma análise do apadrinhamento de cativos em São João del Rei, 1730-1850», Anais do XIV Encontro Nacional de Estudos Populacionais, Associação Brasileira de Estudos Populacionais, Brasil, 2004, 1-21. Disponible en http://www.abep.nepo.unicamp. br/site_eventos_abep/PDF/ABEP2004_119.pdf [Consultado: 13/09/2016].

Cortés, Mónica, Poder y conflicto en el siglo XVIII: El caso San Gil-Socorro, Tesis de Grado dirigida por el Dr. Armando Martínez Garnica. Universidad Industrial de Santander, Escuela de Historia, 1993.

Covarrubias Orozco, Sebastián, Tesoro de la lengua castellana o española (1611), Madrid, Editorial Castalia, 1995.

Cruz, Luzia Henrique Da, A freguesia de São Domingos do Prata (MG): Batismo e compadrio de escravos no século XIX, Tesis de maestría dirigida por la Dra. Miridan Britto Knox Falci. Universidade Severino Sombra, Programa de Mestrado em História Social, 2006. Disponible en http://livros01.livrosgratis. com.br/cp009172.pdf [Consultado: 26/12/2017].

Delfino, Leonara Lacerda, «Sub a unção dos santos óleos: Significado do parentesco fictício na freguesia de São Bom Jesus dos Mártires de Pouso Alegre-MG (século XIX)», Fênix. Revista de História e Estudos Culturais, 9, 2, Uberlândia, Brasil, 2012, 1-14.

Diccionario de Autoridades, Madrid, Real Academia Española, 1726-1739. Disponible en http://web.frl.es/DA.html [Consultado: 13/09/2016].

Faria, Shiela de Castro, A colônia em movimiento: Fortuna e familia no cotidiano colonial, Rio de Janeiro, Nova Fronteira, 1998.

Florentino, Manolo y Goés, José Roberto, A paz das senzalas. Famílias escravas e tráfico Atlântico, Rio de Janeiro, c. 1790-c. 1850, Rio de Janeiro, Civilização Brasileira, 1997.

Florentino, Manolo y Goés, José Roberto, «Morfología de la infancia esclava. Río de Janeiro, siglos XVIII y XIX», en Rodríguez Jiménez, Pablo y Manarelli, María Emma (coords.), Historia de la infancia en América Latina, Bogotá, Universidad Externado de Colombia, 2007, 171-186.

Gómes, Luciano Costa, «Compadrio e apadrinhamento de escravos em Porto Alegre, 1772-1800», 6. ${ }^{\circ}$ Encontro Escravidão e Liberdade no Brasil Meridional, Universidade Federal de Santa Catalina, Brasil, 2013, 1-20. Disponible en http://www.escravidaoeliberdade.com.br/site/images/Textos.6/lucianogomes.pdf [Consultado: 13/09/2016].

Gonzalbo Aizpuru, Pilar, Familia y orden colonial, México, El Colegio de México, 2005.

Guerrero, Amado y Martínez, Armando, La provincia de los Comuneros. Orígenes de sus poblamientos urbanos, Bucaramanga, Ediciones UIS, 1997.

Guzmán, Ángela Inés, Poblamiento y urbanismo colonial en Santander (Estudio de 10 pueblos de la región central), Bogotá, Universidad Nacional de Colombia-Centro Editorial, 1987. 
Machado, Cacilda, «As muitas faces do compadrio de escravos: O caso da freguesia de São José dos Pinhais (PR), na passagem do século XVIII para o XIX», Revista Brasileira de História, 26, 52, Brasil, 2006, 49-77.

Maia, Moacir Rodrigo Castro, «Tecer redes, proteger relações: portugueses e africanos na vivencia do compadrio (Minas Gerais, 1720-1750)», Topoi. Revista de História, 11, 20, Río de Janeiro, 2010, 36-54.

Masferrer León, Cristina V., Muleke, negritas y mulatillos. Niñez, familia y redes sociales de los esclavos de origen africano en la ciudad de México, siglo XVII, México, Instituto Nacional de Antropología e Historia, 2013.

McFarlane, Anthony, Colombia antes de la independencia. Economía, sociedad y política bajo el dominio borbón, Bogotá, El Áncora, 1997.

Nacif, Paulo Cezar Miranda, Diante da pia batismal: As alianças de compadrio em Minas Gerais durante o período colonial, Tesis de maestría dirigida por la Dra. Sheila Siquieria de Castro Faria. Universidade Federal Fluminense, Programa de Pós-gradução em História, 2014. Disponible en http://www. historia.uff.br/stricto/td/1855.pdf [Consultado: 19/12/2017].

O'toole, Rachel Sarah, Bound lives: Africans, Indians, and the Making of Race in Colonial Peru, Pittsburgh, University of Pittsburgh Press, 2012.

Oviedo, Basilio Vicente de, Cualidades y riquezas del Nuevo Reino de Granada, Bogotá, Imprenta Nacional, 1930.

Pereira, Ana Luiza Castro, «Batismo e solidaridade na Vila de Sabará, 1723-1757», Boletim de História Demográfica, 34, Brasil, 2004, 1-13. http://historia_ demografica.tripod.com/bhds/bhd34/sabara.pdf [Consultado: 10/09/2016].

Perera Díaz, Aisnara y Meriño Fuentes, María de los Ángeles, Esclavitud, familia y parroquia en Cuba: Otra mirada desde la microhistoria, Santiago de Cuba, Editorial Oriente, 2006.

Periáñez Gómez, Rocío, La esclavitud en Extremadura (siglos XVI-XVIII), Tesis doctoral dirigida por las Dras. Rocío Sánchez Rubio e Isabel Testón Núñez. Universidad de Extremadura, Área de historia moderna del Departamento de Historia, 2008. Disponible en http://biblioteca.unex.es/tesis/9788469263150. pdf [Consultado: 12/12/2017].

Proctor III, Frank T., «La familia y la comunidad esclava en San Luis Potosí y Guanajuato, Nueva España, 1640-1750», en Cáceres, Rina (comp.), Rutas de la esclavitud en África y América Latina, San José, Editorial de la Universidad de Costa Rica, 2001, 223-249.

Salazar Carreño, Robinson, Tierra y mercados. Campesinos, estancieros y hacendados en la jurisdicción de la villa de San Gil en el siglo XVIII, Bogotá, Ediciones Uniandes, 2011.

Salazar Carreño, Robinson, Familias de esclavos en la villa de San Gil (Nuevo Reino de Granada), 1700-1779: Parentesco, supervivencia e integración social, Tesis doctoral dirigida por la Dra. Solange Alberro. El Colegio de México, Centro de Estudios Históricos, 2017. Disponible en https://colmex. 
userservices.exlibrisgroup.com/view/delivery/52COLMEX_INST/1275940 980002716 [Consultado: 15/01/2018].

Schwartz, Stuart B., Slaves, peasants and rebels: reconsidering Brazilian Slavery, Urbana, University of Illinois Press, 1992.

Schwartz, Stuart B., Segredos internos: Engenhos e escravos na sociedade colonial, 1550-1835, São Paulo, Das Letras, 1995.

Scott, Ana Silvia Volpi, «Familia y compadrazgo en la América Portuguesa (c. 1770-c. 1800)», en Ghirardi, Mónica (coord.), Familias iberoamericanas ayer y hoy. Una mirada interdisciplinaria, Río de Janeiro, Asociación Latinoamericana de Población, 2008, 135-150.

Sirtori, Bruna y Gil, Tiago Luiz, «Bom día, padrinho: espaço e parentesco na formação de redes entre cativos nos Campos de Vacaria, 1778-1810», Revista eletrônica de História do Brasil, 10, 1-2, Brasil, 2008, 142-160. Disponible en http://www.ufjf.br/rehb/files/2010/03/v10-n1e2-a10.pdf [Consultado: $10 / 09 / 2016]$.

Slenes, Robert, «Senhores e subalternos», en Novais, Fernando A. (coord.), História da vida privada no Brasil 2. Império: a corte e a modernidade nacional, São Paulo, Companhia das Letras, 1997, 233-290.

Tovar Pinzón, Hermes, Tovar M., Camilo y Tovar M., Jorge, Convocatoria al poder del número. Censos y estadísticas de la Nueva Granada 1750-1830, Santafé de Bogotá, Archivo General de la Nación, 1994.

Venâncio, Renato Pinto, «Compadrio e rede familiar entre forras de Vila Rica, 1713-1804», Anais da V Jornada Setecentista, Universidad Federal de Paraná, Curitiba, 2003, 598-607. Disponible en http://www.humanas.ufpr.br/ portal/cedope/files/2011/12/Compadrio-e-rede-familiar-entre-forras-de-VilaRica-1713-1804-Renato-Pinto-Ven\%C3\%A2ncio1.pdf [Consultado: 14/09/2016].

Venâncio, Renato Pinto; Sousa, María José Ferro de y Pereira, Maria Teresa Gonçalves, «O compadre governador: redes de compadrio em Vila Rica de fins do século XVIII», Revista Brasileira de História, 26, 52, Brasil, 2006, 273-294. 